(1)

CrossMark

\title{
Urban air quality and health: two steps forward, one step back
}

\author{
Frank J. Kelly \\ Affiliation: Dept of Analytical, Environmental and Forensic Sciences, School of Population Health and \\ Environmental Sciences, King's College London, London, UK. \\ Correspondence: F.J. Kelly, Dept of Analytical, Environmental and Forensic Sciences, School of Population \\ Health and Environmental Sciences, Franklin-Wilkins Building, 150 Stamford St, London SE1 9NH, UK. \\ E-mail: frank.kellyakcl.ac.uk
}

@ERSpublications

Those who question the basis of the WHO health-based air quality guidelines need to consider the totality of evidence http://ow.ly/aOpE30nVtuZ

Cite this article as: Kelly FJ. Urban air quality and health: two steps forward, one step back. Eur Respir J 2019; 53: 1900280 [https://doi.org/10.1183/13993003.00280-2019].

Air pollution in the form of particulate matter $(\mathrm{PM})$, nitrogen dioxide $\left(\mathrm{NO}_{2}\right)$ and ground level ozone $\left(\mathrm{O}_{3}\right)$ all cause harm to human health. Across Europe, high concentrations of these air pollutants continue to have a negative impact on citizens, especially those living in urban areas. Air pollution also has marked economic impacts, leading to shorter lives, increased medical costs and reduced productivity. Air pollution also negatively impacts ecosystems, damaging lakes and rivers, and reduces agricultural yields.

Road transport is one of Europe's main sources of air pollution, especially harmful PM and $\mathrm{NO}_{2}$ [1]. Until a few years ago, diesel vehicles were regarded as the "green" option when choosing a new car, chiefly because they offered better fuel consumption and less $\mathrm{CO}_{2}$ emissions than petrol cars. This image, however, quickly changed when it was realised that diesel vehicle of $\mathrm{PM}$ and $\mathrm{NO}_{2}$ exceed those from petrol cars. Moreover, diesel vehicle emissions contain harmful carcinogens, such as polyaromatic hydrocarbons (PAHs).

Compounding this problem, poor emission regulations have been shown to be ineffective for diesel vehicles, such that nitrogen oxides $\left(\mathrm{NO}_{\mathrm{x}}\right)$ emissions have not reduced significantly over the past 20 years; such emissions are harmful in themselves and also act as precursors of "acid rain" and $\mathrm{O}_{3}$. Diesel emissions dramatically came under the spotlight in 2015 when Volkswagen was caught cheating regulatory tests. Caught red-handed by the American authorities, several senior staff were found to be on the wrong side of the law for their actions. If this was not enough to shake consumer confidence in diesel, independent tests demonstrated that virtually all diesel cars were pumping out more pollution under "real-world" driving conditions than in official tests conducted by the car manufacturers in their factories.

The legacy of the "race for diesel" has resulted in most European cities breaching EU air quality limit values for $\mathrm{NO}_{2}$ since 2010. With community groups and non-governmental organisations such as Client Earth taking European countries (e.g. UK) or cities (e.g. Hamburg) to court, cities have needed to resort to the introduction of clean air zones, which restrict certain classes of vehicles, such a pre-Euro 6 diesel cars. With increasing numbers of cities resorting to such action, including Berlin, Bonn, Düsseldorf, Hannover, Cologne, Munich and Stuttgart, the German car industry is beginning to feel the impact of reduced diesel sales and now, it seems, is beginning to fight back.

This started with the recent publication of a letter [2] by a retired German pulmonologist and 107 of his fellow professionals questioning the basis of the EU's air quality limit values and the World Health Organization (WHO) process that produces regular update recommendation of the air quality guidelines. 
This view, questioning the legitimacy of air quality health-based guidelines, goes against decades of careful investigation and experimental medicine by tens of thousands of scientists across the globe. The dissenters focused particularly on epidemiological studies that link increased exposure to air pollution over long periods of time and increased health outcomes, including shorter life spans. Mortality estimated in terms of "premature deaths" and as "years of life lost" as an outcome is one of the most robust findings associated with air pollution. Such estimates provide a measure of the general impact of air pollution across a given population, but should not be assigned to an individual living in a specific geographical location, an unfortunate common misconception illustrated well by Professor Köhler's statement that he had never seen anyone die from breathing PM pollution.

Furthermore, air pollution has been shown to contribute to the development of pulmonary and cardiovascular diseases [3], and has been linked with adverse effects on fetal development during pregnancy [4] and lung growth restrictions in schoolchildren [5]. These, and thousands of other such studies, confirm the need for WHO health-based air quality guidelines and their translation in European law as air quality limit values. It is therefore unclear why Professor Köhler should now question this science. Epidemiological studies, however, only make up only part of the air pollution and health evidence base, pointing the way to "possible associations" between the two but falling short of assigning accountability. Instead, another branch of science fills this gap in the form of toxicological studies which can demonstrate direct and quantifiable measures of exposure to air pollutants.

Toxicology has been able to demonstrate that the health impacts of exposure to air pollution are diverse and, in particular, impact heavily on the cardiovascular system [6-9]. Effects are manifested through several, likely overlapping, pathways including endothelial dysfunction, atherosclerosis, pro-coagulant changes, alterations in autonomic nervous system balance and changes in blood pressure [6]. At the molecular level, the principal pathways involved in eliciting such effects depend upon the nature of the air pollutants (i.e. PM plus their components versus gases). These include 1) the instigation of an inflammatory response within the alveoli, causing secondary systemic inflammation via pulmonary and systemic oxidative injury which, via pro-oxidative and/or proinflammatory mediators, brings about or exacerbates cardiovascular responses [10];2) the translocation of ultrafine and nano-sized particles and/or PM constituents (organic compounds, metals) across the alveolar membrane into the systemic circulation, possibly giving rise to direct interaction and localised toxicity within the vascular endothelium and/or cardiac tissue [11, 12]; and 3) the activation of airway-sensitive receptors or nerves and subsequent autonomic nervous system imbalance [13]. Human studies encompassing controlled, occupational, panel and cross-sectional analyses have detected associations between exposure and biomarker molecules that are formed by the action of oxidants on lipids (e.g. malondialdehyde, 8-isoprostane) or nucleic acids (e.g. 8-oxo-7,8-dihydro-2'-deoxyguanosine) [14]. These studies, in turn, helped to translate research investigating potential mechanistic pathways in healthy and diseased animal models, isolated organs and cell cultures where evidence of a contributory role of oxidative stress in the target tissue has been documented [15-17] following exposure.

Professor Köhler also enters difficult territory when he tries to compare the short-term peaks of exposure experienced during smoking with the long-term outcomes of regular exposure to ambient pollution. Such comparisons have no scientific basis and can only lead to further misunderstanding regarding the impact of low-level air pollutant exposures.

In conclusion, the combined epidemiological and toxicological evidence base linking exposure to air pollution and adverse health outcomes is robust and defensible. Should those who want to prevent the car industry from further diversification from fossil fuel use want to pick a fight, I strongly suggest they should look elsewhere as this particular horse has already bolted.

Conflict of interest: F.J. Kelly has nothing to disclose.

\section{References}

1 European Environment Agency. Air Quality in Europe - 2018 Report. Luxembourg, Publications Office of the European Union.

2 Köhler D, Hetzel M, Klingner $\mathrm{M}$, et al. Stellungnahme zur Gesundheitsgefährdung durch umweltbedingte Luftverschmutzung, insbesondere Feinstaub und Stickstoffverbindungen $\left(\mathrm{NO}_{\mathrm{x}}\right)$ [Opinion on the health risk posed by environmental pollution, in particular fine dust and nitrogen compounds $\left(\mathrm{NO}_{\mathrm{x}}\right)$ ]. www.lungenaerzte-im-netz. de/fileadmin/pdf/Stellungnahme_NOx_und_Feinstaub.pdf Date last accessed: February 25, 2019.

3 World Health Organization. Review of the Evidence on Health Aspects of Air Pollution - REVIHAAP. Technical Report. Copenhagen, WHO Regional Office for Europe, 2013; p. 309.

4 Stieb DM, Chen L, Eshoul M, et al. Ambient air pollution, birth weight and preterm birth:a systematic review and meta-analysis. Environ Res 2012; 117: 100-111.

5 Mudway IS, Dundas I, Wood HE, et al. Impact of London's low emission zone on air quality and children's respiratory health: a sequential annual cross-sectional study. Lancet Public Health 2019; 4: e28-e40. 
6 Brook RD, Rajagopalan S, Pope CA III, et al. Particulate matter air pollution and cardiovascular disease: an update to the scientific statement from the American Heart Association. Circulation 2010; 121: 2331-2378.

7 Franchini M, Mannucci PM. Short-term effects of air pollution on cardiovascular diseases: outcomes and mechanisms. J Thromb Haemost 2007; 5: 2169-2174.

8 Mustafic $\mathrm{H}$, Jabre $\mathrm{P}$, Caussin $\mathrm{C}$, et al. Main air pollutants and myocardial infarction: a systematic review and meta-analysis. JAMA 2012; 307: 713-721.

9 Pope CA, Dockery DW. Health effects of fine particulate air pollution: lines that connect. J Air Waste Manag Assoc 2006; 56: 709-742.

10 Miller MR, Borthwick SJ, Shaw CA, et al. Direct impairment of vascular function by diesel exhaust particulate through reduced bioavailability of endothelium-derived nitric oxide induced by superoxide free radicals. Environ Health Perspect 2009; 117: 611-616.

11 Moller P, Mikkelsen L, Vesterdal LK, et al. Hazard identification of particulate matter on vasomotor dysfunction and progression of atherosclerosis. Crit Rev Toxicol 2011; 41: 339-368.

12 Miller MR. The role of oxidative stress in the cardiovascular actions of particulate air pollution. Biochem Soc Trans 2014; 42: 1006-1011.

13 Perez CM, Hazari MS, Farraj AK. Role of autonomic reflex arcs in cardiovascular responses to air pollution exposure. Cardiovasc Toxicol 2015; 15: 69-78.

14 Delfino RJ, Staimer N, Vaziri ND. Air pollution and circulating biomarkers of oxidative stress. Air Qual Atmos Health 2011; 4: 37-52.

15 Weichenthal SA, Godri-Pollitt K, Villeneuve PJ. PM2.5, oxidant defence and cardiorespiratory health: a review. Environ Health 2013; 12: 40.

16 Brook RD, Rajagopalan S. Particulate matter, air pollution, and blood pressure. J Am Soc Hypertens 2009; 3: 332-350.

17 Chuang HC, Hsueh TW, Chang CC, et al. Nickel-regulated heart rate variability: the roles of oxidative stress and inflammation. Toxicol Appl Pharmacol 2013; 266: 298-306. 